\title{
Fruit Quality Attributes of Sour Cherry Cultivars
}

\author{
Tomo Miloševićc ${ }^{1}$ and Nebojša Miloševićc ${ }^{2}$ \\ ${ }^{1}$ Department of Fruit Growing and Viticulture, Faculty of Agronomy, Cara Dusana 34, 32000 Cacak, Serbia \\ ${ }^{2}$ Department of Pomology and Fruit Breeding, Fruit Research Institute, Kralja Petra I/9, 32000 Cacak, Serbia
}

Correspondence should be addressed to Tomo Milošević, tomom@tfc.kg.ac.rs

Received 18 August 2011; Accepted 27 September 2011

Academic Editor: N. Maruyama

Copyright ( 2012 T. Milošević and N. Milošević. This is an open access article distributed under the Creative Commons Attribution License, which permits unrestricted use, distribution, and reproduction in any medium, provided the original work is properly cited.

\begin{abstract}
The aim of this study is the evaluation of two sour cherry cultivars (“Oblačinska", "Cigančica”) grown at Cacak (Western Serbia) by determining main physical properties such as fruit linear dimensions, arithmetic and geometric mean diameter, fruit volume, sphericity, surface area, and aspect ratio at the commercial stage. Also, some attributes related to fruit quality (fruit weight, soluble solids, total acidity, ripening index, and $p H$ juice) were evaluated at different ripening stages. "Oblačinska" shows better physical properties, except aspect ratio, when compared with "Cigančica". Sphericity was similar in both cultivars. Fruit weight, soluble solids content, ripening index, and $p H$ increased during ripening process, whereas titratable acidity decreased over above process. In general, "Oblačinska" had better chemical composition than "Cigančica”. Finally, fruit of both cultivars is suitable for processing and also for fresh consumption.
\end{abstract}

\section{Introduction}

Sour cherry (Prunus cerasus L.) is an allotetraploid species, originating from a natural hybridization between sweet cherry ( $P$. avium L.) and ground cherry ( $P$. fruticosa Pall.) [1]. The distribution of European sour cherry ranges from the Mediterranean islands to northern Russia, and, within the range there is a wide diversity of different plant habitats and fruit characters [2]. Sour cherries (P. cerasus L.) are most popular as fruit crop and in fruit industry. In 2009, Serbia (having cultivated area with 38,000 hectares and with annual production of 105,353t) was the sixth largest producers of this species in the world [3]. Also, Serbia can be regarded as important frozen and fresh fruit sour cherry exporter [4]. According to above author, the most common cultivars in Serbian sour cherry orchards were "Oblačinska" and "Cigančica" (also called "Cigány maggy" or "Cigány") that belong to P. cerasus L. The "Oblačinska" is an autochthonous and heterogeneous Serbian cultivar, whereat "Cigančica" native to Hungary and grown worldwide [4-6]. Both cultivars displayed great phenotypic variability.

The fruit of the above cultivars, especially of "Oblačinska", is of "morello" type, small to medium in size, with dark red and thin skin. The flesh is red, medium firm, juicy, quite sour, aromatic, and of high quality. In addition, the "Oblačinska" is highly resistant to leaf spot and to bitter rot [7]. Also, this cultivar is self-compatible and characterized by regular and high yield. From this point, the numerous positive traits of both cultivars should make it interesting for plantation in other countries.

Fruit of sour cherry is a drupe, round or heart-shaped, glabrous, and with pedicel attached [6]. After pollination and fruit set, fruit developed through growth and maturation. Growth represents a quantitative process, which conducts to increase of fruit weight and volume [8]. Fruit maturation is characterized by changes in physiological, biochemical, and morphological treats of the fruit, which determine the qualitative characteristics of any cultivar and finally its depreciation during senescence. Changes in cherries upon ripening are easily apparent by looking at their color change from green to red [9]. Fruit ripening is associated with important chemical changes, and color change is mainly influenced by the concentration and distribution of different anthocyanins in the skin [10]. From this point, total anthocyanins, that is, color in red fruit increases during ripening [11]. Color of red fruit is indicator of maturity and important 
parameter of commercial harvest date [12]. Additionally, skin of sour cherry fruits was generally bright-to-dark red in color and exhibits less color variation than sweet cherries [6].

Numerous studies have been done on physical and chemical change in sweet cherries during maturation [1214], while studies on sour cherries are rare. Also, no detailed study concerning physical and chemical properties of sour cherry has been performed up to now. The aim of this study was to determine some physical and chemical properties of two sour cherry cultivars during different stages of ripening.

\section{Material and Methods}

2.1. Plant Material and Experimental Design. Present study was carried out at village Prislonica $\left(43^{\circ} 57^{\prime} \mathrm{N}, 20^{\circ} 26^{\prime}\right.$ E, $322 \mathrm{~m}$ above sea level) near Cacak (Western Serbia) during 2010 and 2011 on "Oblačinska" and "Cigančica" sour cherry cultivars produced by suckers. The orchard was established in 2004. The tree densities on the experimental area were 1,250 trees ha ${ }^{-1}$ (planting spacing $4 \mathrm{~m} \times 2 \mathrm{~m}$ ). Annually, standard cultural practices (pruning, thinning, fertilization, pest control, and treatments) were performed, except irrigation. Fertilizers were applied according to soil analyses. This way ensured the optimum conditions for trees to grow and bear fruit.

Weather conditions of Cacak are characterized by the average annual temperature of $11.3^{\circ} \mathrm{C}$ and total annual rainfall of $690.2 \mathrm{~mm}$. Soil at the orchard is classified as vertisol according to Serbian Soil Taxonomy. Soil texture is clay-loam, moderate in organic matter, and total nitrogen $\left(\mathrm{N}_{\text {Tот }}\right)(1.97 \%$ and $0.17 \%$, resp.); soil $\mathrm{pH}$ in $0.01 \mathrm{M} \mathrm{KCl}$ was 6.67 and no soluble salt problem in $0-30 \mathrm{~cm}$ soil depth. The contents of $\mathrm{P}_{2} \mathrm{O}_{5}$ and $\mathrm{K}_{2} \mathrm{O}$ in this soil depth were high, that is, $330 \mathrm{mg} \mathrm{kg}^{-1}$ and $350 \mathrm{mg} \mathrm{kg}^{-1}$, respectively.

Twenty representative trees within each replicate were selected for sampling and data collection. The four replicates were arranged in a randomized completely block design.

\subsection{Fruit Physical and Chemical Measurements. For each} cultivar, 25 homogeneous fruits in four replications were harvested at four ripening stages $\left(S_{1}\right.$ to $\left.S_{4}\right)$, according to fruit color and size. Sour cherry fruits at $S_{1}$ were in the last growth phase having a light red color, while at $S_{4}$ they have reached the commercial ripening stage to be harvested. In $\mathrm{S}_{4}$-ripening stage, fruits have dark-red skin color. Thus, $\mathrm{S}_{1-}$ $S_{4}$ corresponded to $S_{11}-S_{14}$ stages described for cherry fruit growth and ripening on tree by Serrano et al. [15].

The fruit weight $(F W)$ for each fruit during maturation was determined using a digital balance (Tehnica ET-1111, Iskra, Slovenia) to an accuracy of $0.01 \mathrm{~g}$, and results were the mean $\pm \mathrm{SE}(\mathrm{g})$. For each sour cherry fruit in last stage $\left(\mathrm{S}_{4}\right)$, three linear dimensions, length $(L)$, width $(W)$, and thickness $(T)$, were measured by using a digital caliper gauge with a sensitivity of $0.001 \mathrm{~cm}$. The measurement of $L$ was made on the polar axis of fruit, that is, between the apex and stem. The arithmetic mean diameter $\left(D_{a}\right)$, geometric mean diameter $\left(D_{g}\right)$, fruit volume $(F V)$, sphericity $(\phi)$, and surface area $(S)$ was calculated by Mohsenin [16]. The aspect ratio $\left(R_{a}\right)$ was calculated by Maduako and Faborode [17].

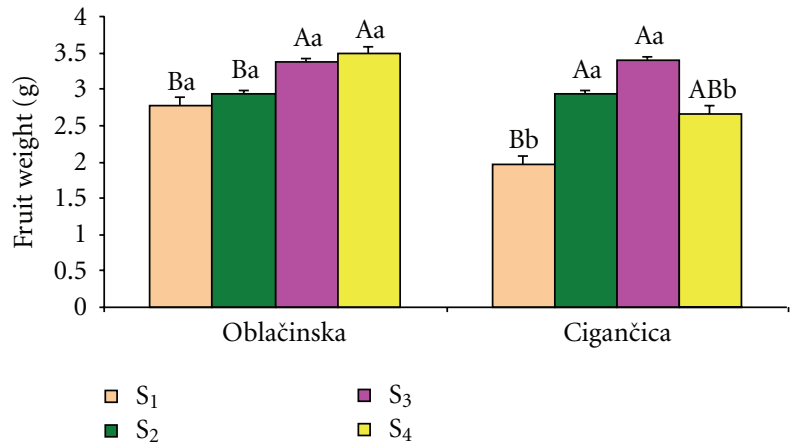

FIGURE 1: Fruit weight evolution from $S_{1}$ - to $S_{4}$-ripening stage in two sour cherry cultivars. Data are mean \pm SE. Different capital letters represent differences between stages for the same cultivar, and lower-case letters represent differences between cultivars within the same stage at 0.05 probability level (LSD test).

Fruit chemical composition measured from $S_{1}$ to $S_{4}$ in triplicate. Soluble solids content (SSC) was determined by Milwaukee MR 200 hand digital refractometer (ATC, Rocky Mount, USA) at $20^{\circ} \mathrm{C}\left({ }^{\circ}\right.$ Brix). Titratable acidity (TA), as malic acid (\%), was determined by titration to $\mathrm{pH} 8.1$ with $\mathrm{N} / 10 \mathrm{NaOH}$. On the basis of the measured data, soluble solids/titratable acidity ratio (SS/TA ratio or ripening index-RI) was calculated. The $p H$ was determined by a Cyber Scan 510 pH meter (Nijkerk, Netherlands). All results expressed as the mean \pm SE for each chemical properties.

2.3. Statistical Analysis. The data obtained from field measurements and laboratory observations were subjected to an analysis of variance using SAS software (SAS Institute Inc., Cary, NC, USA), and the LSD test $(P \leq 0.05)$ procedure was applied. The figures are performed by the Microsoft Excel software (Microsoft Corporation, Roselle, IL, USA).

\section{Results and Discussion}

3.1. Evaluation of Physical Properties. Data presented in Figure 1 indicated that $F W$ of "Oblačinska" continuously increased during ripening period from $S_{1}$ to $S_{4}$ stage. However, FW in $S_{3}$ and $S_{4}$ stage was significantly higher than $F W$ in $S_{1}$ and $S_{2}$. The $F W$ of "Cigančica" also increased from $S_{1}$ to $S_{3}$ stage, and decreased from $S_{3}$ to $S_{4}$ (Figure 1). In this case, $F W$ in $S_{2}$ and $S_{3}$ was higher than $F W$ in $S_{1}$. Differences between cultivars within the same stage were significant in $S_{1}$ and in $S_{4}$, that is, "Oblačinska" showed a larger fruit than "Cigančica" in $S_{1}$ and $S_{4}$ stages (Figure 1). Other differences were insignificant. At the commercial ripening stage $\left(\mathrm{S}_{4}\right)$, the values were $3.48 \pm 0.11 \mathrm{~g}$ for "Oblačinska" and $2.66 \pm 0.09 \mathrm{~g}$ for "Cigančica." This seems to represent a major advantage for the growers. Similar tendency for fruit weight changes during ripening observed in a previous study on cherry cultivars [14]. Also, earlier work reported a high variability among cherry cultivars regarding this parameter $[4,11,12$, 14, 18]. According to Nikolić et al. [19], fruit weight in different clones of "Oblačinska" under Belgrade (Serbia) climatic conditions varied between $2.97 \mathrm{~g}$ and $5.01 \mathrm{~g}$, whereas 
TABLE 1: Dimensional properties of two sour cherry cultivars in final ripening stage $\left(\mathrm{S}_{4}\right)$. Data are average values for 2010 and 2011 and expressed as mean $\pm \mathrm{SE}$.

\begin{tabular}{lcc}
\hline Properties & Oblačinska & Cigančica \\
\hline Fruit length $(\mathrm{mm})$ & $14.85 \pm 0.12 \mathrm{a}$ & $14.27 \pm 0.19 \mathrm{~b}$ \\
Fruit width $(\mathrm{mm})$ & $15.50 \pm 0.09 \mathrm{a}$ & $15.23 \pm 0.15 \mathrm{~b}$ \\
Fruit thickness $(\mathrm{mm})$ & $17.44 \pm 0.10 \mathrm{a}$ & $16.87 \pm 0.22 \mathrm{~b}$ \\
Arithmetic mean diameter $(\mathrm{mm})$ & $15.93 \pm 0.09 \mathrm{a}$ & $15.46 \pm 0.16 \mathrm{~b}$ \\
Geometric mean diameter $(\mathrm{mm})$ & $15.89 \pm 0.09 \mathrm{a}$ & $15.42 \pm 0.16 \mathrm{~b}$ \\
Fruit volume $\left(\mathrm{cm}^{3}\right)$ & $3.48 \pm 0.21 \mathrm{a}$ & $3.28 \pm 0.11 \mathrm{~b}$ \\
Sphericity & $1.07 \pm 0.00 \mathrm{a}$ & $1.08 \pm 0.01 \mathrm{a}$ \\
Surface area $\left(\mathrm{mm}^{2}\right)$ & $793.28 \pm 9.57 \mathrm{a}$ & $747.11 \pm 15.86 \mathrm{~b}$ \\
Aspect ratio & $104.42 \pm 0.82 \mathrm{~b}$ & $106.81 \pm 0.99 \mathrm{a}$ \\
\hline
\end{tabular}

Different lower-case letters in some rows represent differences between cultivars for the physical properties at 0.05 probability level by LSD test.

Khorshidi and Davarynejad [20] reported that fruit weight of "Cigančica" in Iranian conditions was $2.81 \mathrm{~g}$. Obtained results concur with the findings of above authors. Thus, our results seem to indicate that fruit weight has a strong genetic influence, accordingly with Papp et al. [18]. Also, this property may be useful in the separation and transportation of the cherry fruit by hydrodynamic means [21].

In relation fruit dimensions $(L, W, T), D_{a}, D_{g}$, and $F V$ in last (final) stage $\left(\mathrm{S}_{4}\right)$, "Oblačinska" had significantly higher above values than "Cigančica", whereas $\phi$ values were similar in both cultivars (Table 1). In contrast, $R_{a}$ was higher in "Cigančica" than in "Oblačinska". Ansari and Davarynejad [6] reported that some fruit physical properties of "Cigančica" such as fruit shape index, fruit diameter, and fruit length caused by pollination treatment, and varied from 0.85 to $1.00,18.50 \mathrm{~mm}$ to $20.29 \mathrm{~mm}$, and $16.23 \mathrm{~mm}$ to $20.21 \mathrm{~mm}$, respectively. Our range values were lower than those obtained by above the authors. The reasons for these differences in fruit dimensions could be due to differences in the growing areas, as previously obtained $[1,5,8]$. The importance of these axial dimensions in determining aperture size of machines, particularly in separation of materials, has been discussed by Mohsenin [16]. These dimensions may be useful in estimating the size of machine components, and it may be useful in estimating the number of fruits to be engaged at a time, the spacing of slicing discs and number of slices expected from an average fruit [22]. Sour cherry fruits have several unique characteristics that set them apart from engineering materials. These properties determine the quality of the fruit, and identification of correlations between changes in these properties makes quality control easier [21]. According to the above authors, knowledge of shape and physical dimensions are important in screening solids to separate foreign materials and in sorting and sizing of cherry fruit.

3.2. Evaluation of Chemical Properties. The SSC significantly increased from $S_{1}$ to $S_{4}$ in both sour cherry cultivars, with values at $S_{5}$ ranging from $16.25 \pm 0.39^{\circ}$ Brix in "Cigančica" to $16.80 \pm 0.32^{\circ}$ Brix in the "Oblačinska" (Figure 2(a)). In the $S_{1}$, $\mathrm{S}_{2}$, and $\mathrm{S}_{3}$ ripening stages, "Cigančica" had higher SSC than

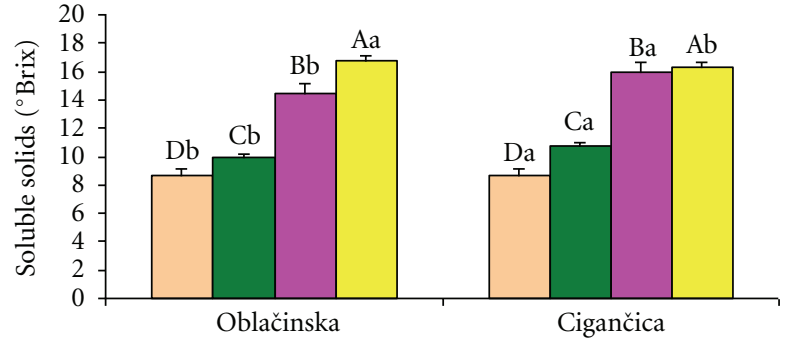

(a)

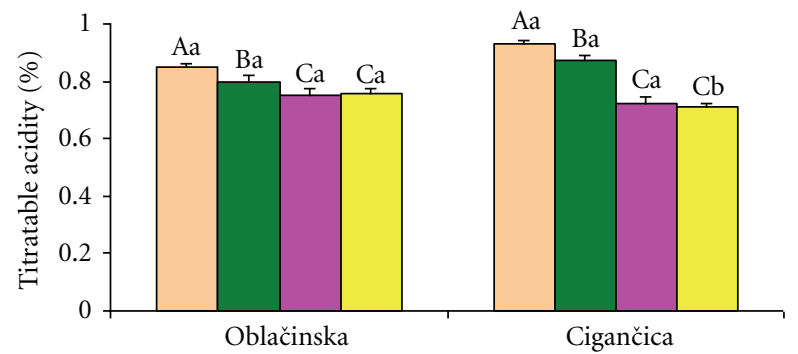

(b)

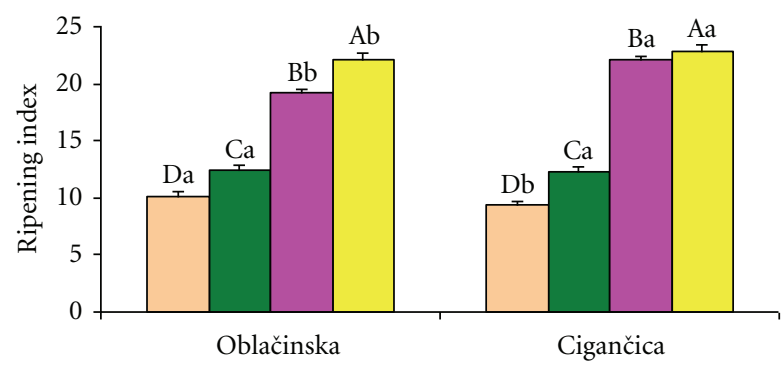

(c)

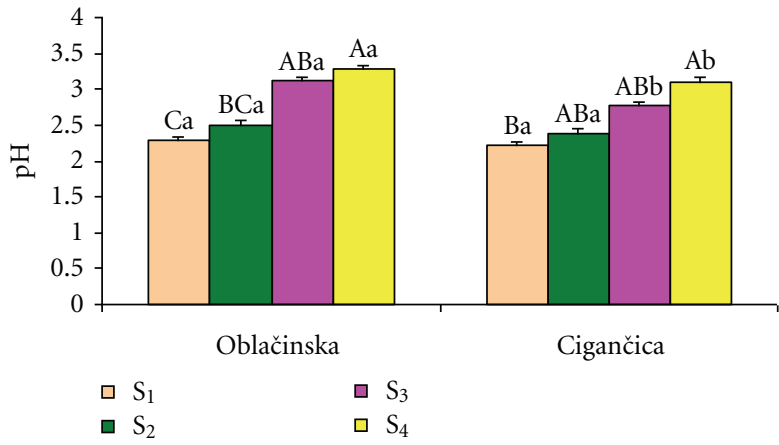

(d)

FIGURE 2: Soluble solids content (a), titratable acidity (b), ripening index (c), and $\mathrm{pH}(\mathrm{d})$ evolution from $\mathrm{S}_{1}$ - to $\mathrm{S}_{4}$-ripening stage in two sour cherry cultivars. Data are mean \pm SE. Different capital letters represent differences between stages for the same cultivar, and lower-case letters represent differences between cultivars within the same stage at 0.05 probability level (LSD test).

"Oblačinska", whereas, in the last stage $\left(\mathrm{S}_{4}\right)$, "Oblačinska" had higher content of this chemical. In an earlier study of Nikolić et al. [19], soluble solids in different clones of "Oblačinska" varied from $14.07 \%$ to 19.06 , while in a previous work of Ansari and Davarynejad [6] for "Cigančica", soluble solids ranged between $14.43 \%$ and $16.24 \%$, and/or 
$18.1^{\circ}$ Brix according to Khorshidi and Davarynejad [20]. Similar tendency for the accumulation of SSC in sweet cherry fruit during ripening has been reported $[14,15]$. Generally, our range values for final SSC and its tendency over ripening process are in a good agreement with results obtained by the above authors.

Significant differences were also found in TA between sour cherry cultivars (Figure 2(b)). Thus, the highest value, harvested at commercial ripening stage $\left(\mathrm{S}_{4}\right)$, was found in fruit of "Cigančica" $\left(0.81 \pm 0.02^{\circ} \mathrm{Brix}\right)$, and the lowest in "Oblačinska" $\left(0.76 \pm 0.01^{\circ} \mathrm{Brix}\right)$. Additionally, $\mathrm{TA}$ significantly decreased from $S_{1}$ to $S_{4}$ ripening stage in both cultivars, and differences between cultivars within the same stage were not significant, except in $S_{4}$ as previously described [12, 14]. According to Nikolić et al. [19], titratable acidity in "Oblačinska" ranged from $1.12 \%$ to $1.54 \%$. In fruit of "Cigančica" grown under Iranian conditions, the TA varied from $1.57 \%$ to $1.89 \%$ [6] or about $2.38 \mathrm{~g} 100 \mathrm{~mL}^{-1}$ [20]. Our results are much lower than previously reported in the literature $[6,19]$. The reasons for these differences in $T A$ could be due to differences in the growing areas $[9,11]$. Also, the great genotypic variability for $T A$ in sour cherry fruit was observed in other study $[5,18]$.

Data presented in Figure 2(c) shows that in both sour cherry cultivars during ripening period, soluble solids/titratable ratio or ripening index $(R I)$ significantly increased for $\sim 54 \%$ in "Oblačinska" and for $\sim 59 \%$ in "Cigančica", which is in agreement with previous study in cherry $[12,14,15]$. The lower $R I$ in fruit harvested at commercial ripening stage $\left(\mathrm{S}_{4}\right)$ was recorded in "Oblačinska" $(22.10 \pm 0.33)$, and higher in "Cigančica" $(22.89 \pm 0.41)$. Our results are much higher than in the literature $[6,19,20]$. Thus, Ansari and Davarynejad [6] reported that "Cigančica" cultivar was not good from the viewpoint of SSC/TA ratio when compared with other Hungarian sour cherry cultivars. However, many authors reported that cultivar, climatic conditions, environmental factors, harvest, and maturity stage can affect the chemical properties in cherries $[8,9,11]$. On the basis of all the above results, we could say that these sour cherry cultivars grown under Cacak pedoclimatic conditions were suitable for processing and also for fresh consumption $[5,23]$.

Fruit $p H$ significantly increased along the ripening process on tree (from $S_{1}$ to $S_{4}$ ) in both sour cherry cultivars, with the highest value being reached in "Oblačinska" $(3.28 \pm 0.06)$ and the lowest in "Cigančica" $(3.10 \pm 0.03)$ (Figure 2(d)). Differences between cultivars within the same stage were insignificant in early stages $\left(S_{1}\right.$ and $\left.S_{2}\right)$, whereas differences in $S_{3}$ - and $S_{4}$-ripening stage were significant. According to Khorshidi and Davarynejad [20], $p H$ in fruit of "Cigančica" was 3.09, which confirmed our results. Also, previous work in sour cherry also reported a high variability among cultivars regarding $p H[18]$.

\section{Conclusion}

As final conclusions, the knowledge of fruit physical and chemical quality attributes of the sour cherry cultivars studied here could be useful to choose the appropriate ones to be grown under Western Serbian climatic conditions or used as parentals in future breeding programs. In this sense, "Oblačinska" had higher fruit weight, fruit dimensions, arithmetic mean diameter, geometric mean diameter, fruit volume, surface area, and best chemical attributes, while "Cigančica" was the better cultivar in terms of higher aspect ratio. Sphericity was similar in both cultivars.

\section{Acknowledgments}

This work has been funded by Serbian Ministry of Science and Technology through Project no. 31064. The authors express their sincerest gratitude to them for their support.

\section{References}

[1] A. F. Iezzoni, "Cherries," in Temperate Fruit Crop Breeding: Germplasm to Genomics, J. F. Hancock, Ed., pp. 151-175, Springer, 2008.

[2] J. A. Beaver, A. F. Iezzoni, and C. W. Ramm, "Isozyme diversity in sour, sweet, and ground cherry," Theoretical and Applied Genetics, vol. 90, no. 6, pp. 847-852, 1995.

[3] FAOSTAT, "Statistics Division, February 10, 2010," 2011, http://faostat.fao.org/.

[4] T. Milosevic, Special Topics in Fruit Growing, Faculty of Agronomy \& Community for Fruits and Vegetables, CacakBelgrade, Serbia, 1997.

[5] J. Nyéki, M. Soltesz, L. Popovics et al., "Strategy of the sour cherry verticum in the northern great plain region Hungary (Analytic study)," International Journal of Horticultural Science, vol. 11, pp. 7-31, 2005.

[6] M. Ansari and G. H. Davarynejad, "Marked improvement of Hungarian sour cherries by cross-pollination II: fruit quality," Asian Journal of Plant Sciences, vol. 7, no. 8, pp. 771-774, 2008.

[7] Z. S. Grzyb and E. Rozpara, "Field evaluation of the susceptibility to Blumeriella jaapi and Glomerella cingulata and some biological properties of newly selected sour cherry genotypes," Journal of Fruit and Ornamental Plant Research, vol. 12, pp. 313-319, 2004.

[8] M. Fleancu, "Correlations among some physiological processes in apple fruit during growing and maturation processes," International Journal of Agriculture and Biology, vol. 9, pp. 613-616, 2007.

[9] S. Pedisić, B. Levaj, V. Dragović-Uzelac, D. Škevin, and M. S. Babojelić, "Color parameters and total anthocyanins of sour cherries (Prunus Cerasus L.) during ripening," Agriculturae Conspectus Scientificus, vol. 74, no. 3, pp. 259-262, 2009.

[10] L. Gao and G. Mazza, "Characterization, quantitation, and distribution of anthocyanins and colourless phenolics in sweet cherry," Journal of Agricultural and Food Chemistry, vol. 43, no. 2, pp. 343-346, 1995.

[11] S. Pedisić, B. Levaj, V. Dragović-Uzelac, and K. Kos, "Physicochemical composition, phenolic content and antioxidant activity of sour cherry cv. Marasca during ripening," Agriculturae Conspectus Scientificus, vol. 72, no. 4, pp. 295-300, 2007.

[12] M. Esti, L. Cinquanta, F. Sinesio, E. Moneta, and M. Di Matteo, "Physicochemical and sensory fruit characteristics of two sweet cherry cultivars after cool storage," Food Chemistry, vol. 76, no. 4, pp. 399-405, 2002.

[13] B. Gonçalves, A. P. Silva, J. Moutinho-Pereira, E. Bacelar, E. Rosa, and S. A. Meyer, "Effect of ripeness and postharvest storage on the evolution of colour and anthocyanins in cherries 
(Prunus avium L.)," Food Chemistry, vol. 103, no. 3, pp. 976984, 2007.

[14] F. Garcia-Montiel, M. Serrano, D. Martinez-Romero, and N. Alburquerque, "Factors influencing fruit set and quality in different sweet cherry cultivars," Spanish Journal of Agricultural Research, vol. 8, no. 4, pp. 1118-1128, 2010.

[15] M. Serrano, F. Guillén, D. Martínez-Romero, S. Castillo, and D. Valero, "Chemical constituents and antioxidant activity of sweet cherry at different ripening stages," Journal of Agricultural and Food Chemistry, vol. 53, no. 7, pp. 2741-2745, 2005.

[16] N. N. Mohsenin, Physical Properties of Plant and Animal Materials, Gordon and Breach, New York, NY, USA, 1986.

[17] J. N. Maduako and M. O. Faborode, "Some physical properties of cocoa pods in relation to primary processing," IFE Journal of Technology, vol. 2, pp. 1-7, 1990.

[18] N. Papp, B. Szilvássy, L. Abrankó et al., "Main quality attributes and antioxidants in Hungarian sour cherries: identification of genotypes with enhanced functional properties," International Journal of Food Science and Technology, vol. 45, no. 2, pp. 395-402, 2010.

[19] D. Nikolić, M. Fotirić-Akšić, and V. Rakonjac, "Characteristics of selected Oblacinska sour cherry clones (Prunus cerasus L.)," in Proceedings of the 3rd Conference of Innovations in Fruit Growing, pp. 145-151, Belgrade, Serbia, February 2011.

[20] S. Khorshidi and G. Davarynejad, "Influence of preharvest ethephon spray on fruit quality and chemical attributes of "Cigany" sour cherry cultivar," Journal of Biological and Environmental Sciences, vol. 4, pp. 133-141, 2010.

[21] G. Muskovics, J. Felfoldi, E. Kovacs, R. Perlaki, and T. Kallay, "Changes in physical properties during fruit ripening of Hungarian sweet cherry (Prunus avium L.) cultivars," Scientia Horticulture, vol. 40, pp. 56-63, 2006.

[22] M. Naderiboldaji, A. Khadivikhub, A. Tabatabaeefar, M. G. Varnamkhasti, and Z. Zamani, "Some physical properties of sweet cherry (Prunus avium L.) fruit," American-Eurasian Journal of Agricultural and Environmental Sciences, vol. 3, pp. 513-520, 2008.

[23] C. H. Crisosto, G. M. Crisosto, and P. Metheney, "Consumer acceptance of "Brooks" and "Bing" cherries is mainly dependent on fruit SSC and visual skin color," Postharvest Biology and Technology, vol. 28, no. 1, pp. 159-167, 2003. 


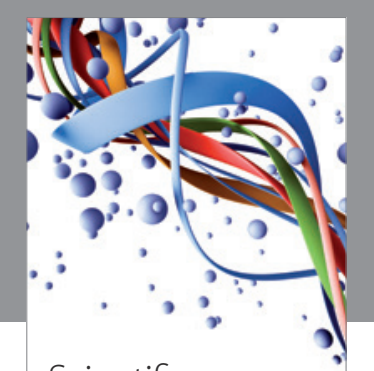

Scientifica
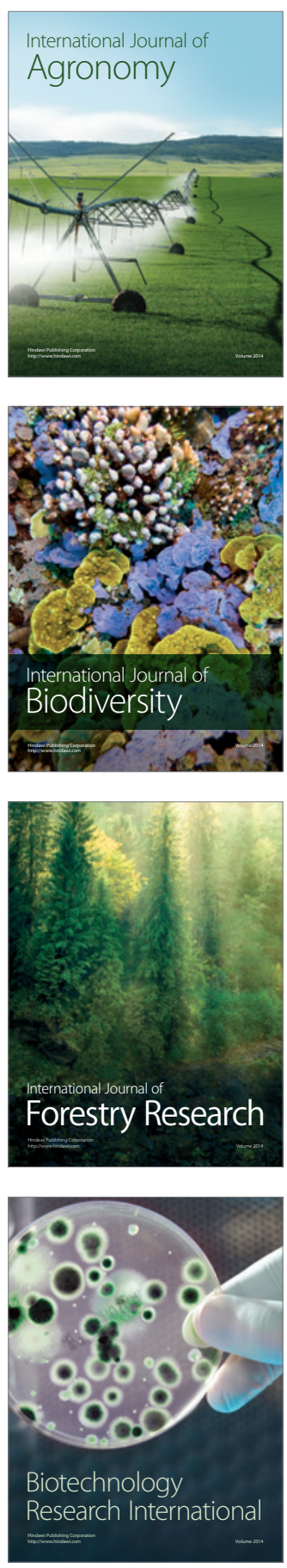
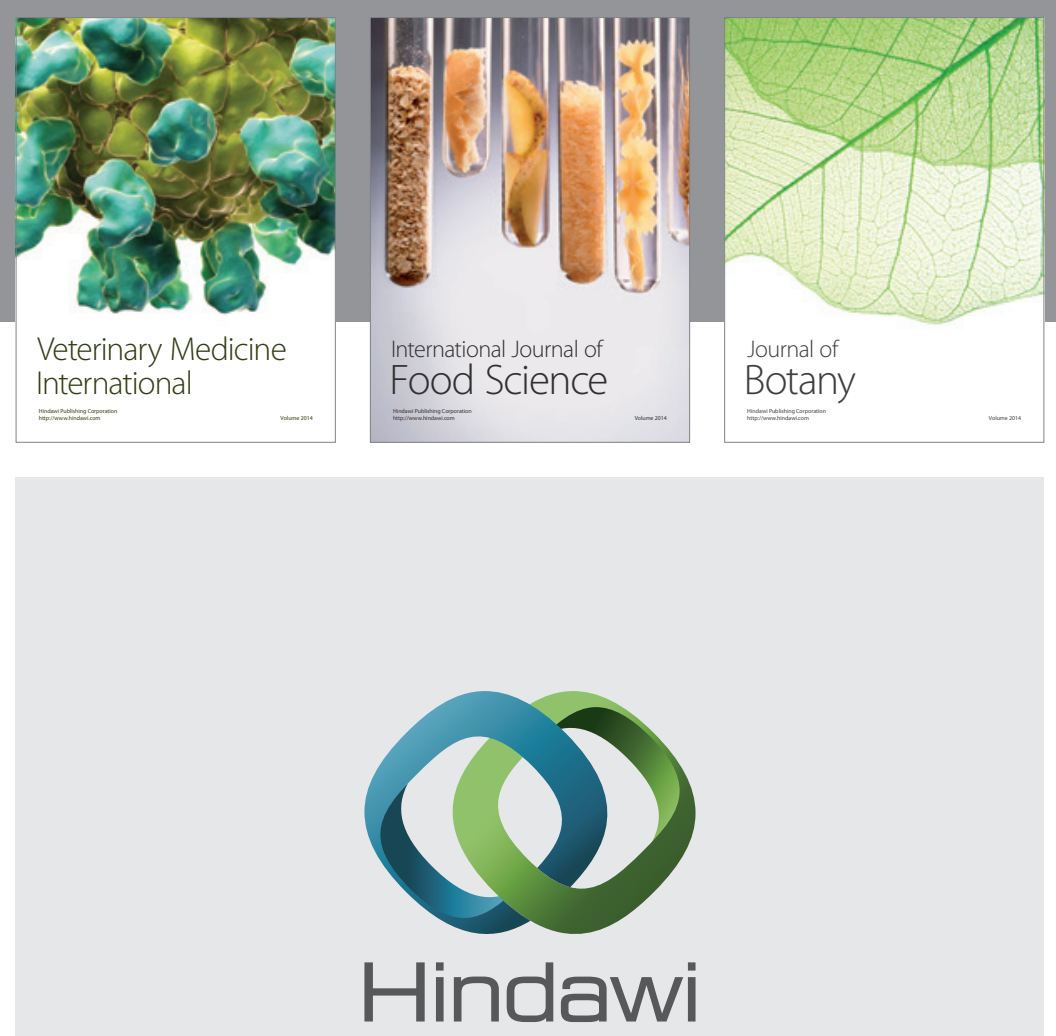

Submit your manuscripts at

http://www.hindawi.com
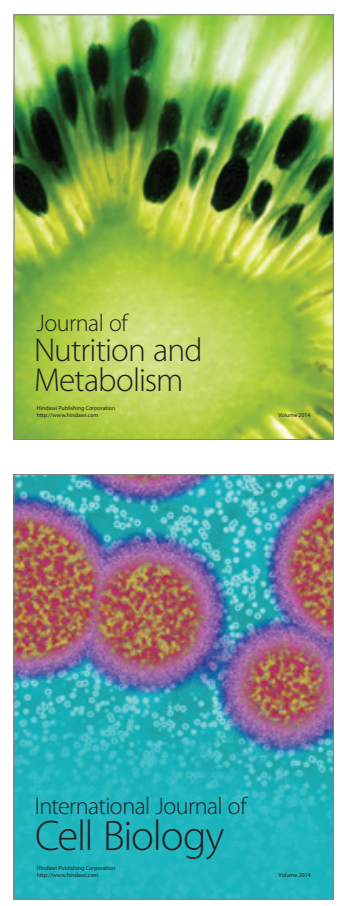
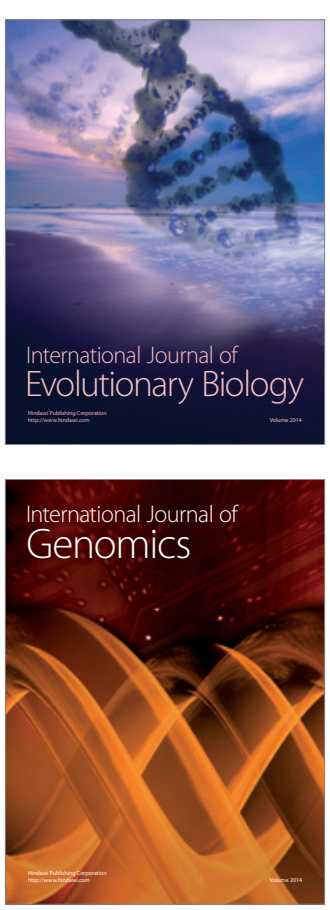
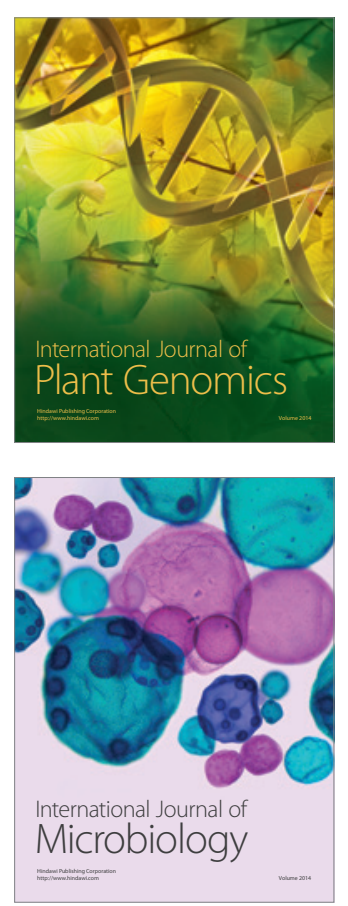

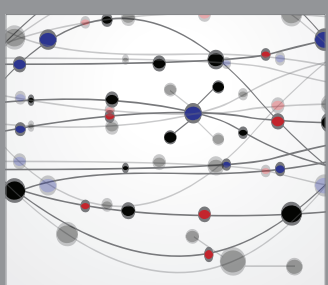

The Scientific World Journal
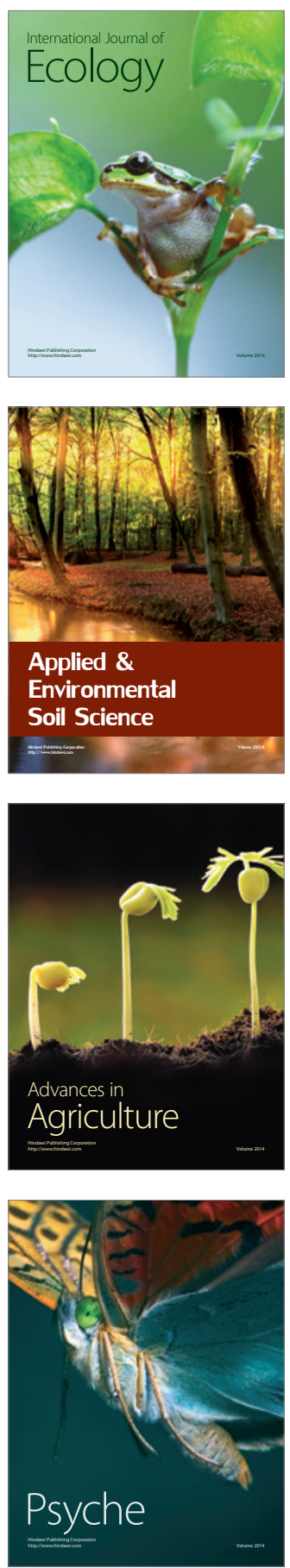